\title{
住民参加のための大震時火災延焼シミュレーション・システム開発
}

\section{Development of Fire-Spreading Simulation System aimed at Residents' Participation under a Big Earthquake}

\author{
二神透 $^{1} \cdot$ 木俣昇 $^{2}$
}

Tohru Futagami, Noboru Kimata

\begin{abstract}
抄録：本論文では，著者らが開発を行っている大震時火災延焼シミュレーションの改 良を行った .具体的には，住民・行政が自らデータを採取できるようシミュレーション・ データの自動採取化を図った .さらに,シミュレーション結果を基に，耐火・不燃化とい つた都市計画や，防火樹木の配置効果といった，具体的な諸対策の効果を把握するための システム開発を試みた . 開発したシステムは , 住民・行政が防災意識を高めるとともに， 避難計画の策定や，避難訓練の実施にも活用できるであろう.最後に，今後の課題を整理 している。
\end{abstract}

\begin{abstract}
In this paper, the fire spreading simulation at the time of large earthquake in which authors have been developing was improved.

Specifically, automatic extraction of simulation data was attained so that residents and administration could extract data by themselves. Furthermore, we developed the system which enables to grasp the effect of many concrete measures based on the simulation, such as city planning, fire-resistance and incombustibility of building, and the arrangement effect of fire prevention trees were applied. The developed system will be utilizable for decision of an evacuation plan, and implementation of a fire drill as well as raises awareness of disaster prevention for the residents and administration. Finally, the future subject is arranged.
\end{abstract}

キーワード： シミュレーション、情報利用、地震火災、防災意識、防火樹木、合意形成

Keywords : simulation, information use, earthquake fire, awareness of disaster prevention, fire prevention trees, consensus building

\section{1.はじめに}

わが国では，木造住宅嗜好が強く，木造密集市 街地が, 各地に存在する. 各自冶体の地震時被害 想定を見れば，これら市街地での火災延焼被害が 必ず取り上げられており，地震時火災リスクへの 認識は広く行き渡っているかに見える.しかし， 谷の認識は, 地震時火災リスクを回避したり，軽 減したりする行動計画へと具現化させ，さらに実 効性のあるものへの改変を促進させるレベルのも のではない .

具体的には，防災計画書の指定避難場所の多く は校区単位の指定であり，被災者への救護や生活 支援での利便性面に重心があり，地震時火災の特 性である同時多発性 , 消火力の低下性への配慮は ほとんど見られないのか現状である . 避難訓練面 でも，多くの場合，指定避難場所への移動体験に 留まっている.近年, ボードを用いて, 火災や建 物倒壊による通行阻害情報を付与するという試み がなされるようになつたが, 試みレベルに留まつ ている.例えば, 2007 年に愛媛県新居浜市防災安
全課が実施した小学校区単位の避難訓練では，" 家屋の倒壊”，" 火災の発生”といったカードを 事前に玄関先に置き, “避難時に発見者が回収し てください”という広報で，事前周知を図ったと しているが，一枚の回収さえ行われなかった .こ のことは，住民側のみならず，計画者側の認識レ ベルにも問題があることを示唆しているだろう .

本論文では，著者らが開発を行っている大震時 火災延焼シミュレーション ${ }^{1)-7)}$ を改良し，住民・ 行政が自らデータを採取し，地域の地震火災危険 性を評価可能なシステムを提案する．すなわち， 住民自ら，耐火・不燃化といった都市計画や，防 火樹木の配置効果といった，具体的な諸対策の効 果を把握するためのシステム開発を試み今後の課 題を整理している.

\section{2. 都市構造データ採取のシステム化}

\section{（1）従来のシステムにおけるデータ入力}

大震時の火災延焼速度式に関するモデルは，浜 田・堀内，室崎，東消式など樣々なモデルが開発

1：正会員 学博 愛媛大学 講師 総合情報メディアセンター

(下790-8577 松山市文京町3, Tel :089-927-9837)

2：正会員 工博 金沢大学名誉教授 


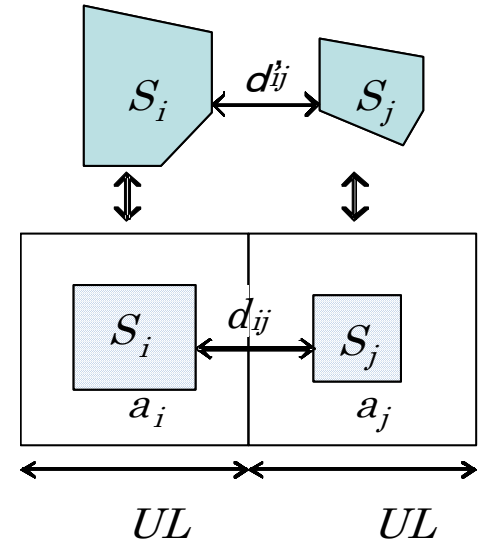

図-1 ポリゴン建物とメッシュモデル化

されている . 著者らの開発している大震時の火災 延焼シミュレーション・システムは, 著者らが実 火災との整合性検証 ${ }^{1), 21}$ を行った浜田らの延焼速 度式 6)に基礎を置いた，図-1に示すようなメッシ ユ型モデルを採用している .すなわち, 図上の面 積 S とSポリゴン間の隣棟間隔 $d^{\prime}{ }_{i j}$ は, 図-1の 下側の正方メッシュ建物 S ( 建物長 $a_{i}$ ) とS（建 物長 $a_{j}$ ) との距離 $d_{i j}$ で定義される.ポリゴン建 物は，木造建物，防火木造建物，耐火造建物に区 別している .メッシュ間の延焼時間は, 上述した パラメータと, メッシュ内の建物混成比ならびに 気象条件 (風向，風速) を与えてシミュレーショ ンを実行する . ダイナミックな延焼ならびに鎮火 の状態は, メッシュの延焼状態をポリゴン建物へ 反映化して表示している .

既往システムでは, 対象とする地域の住宅地図 あるいは航空写真を用いて, ポリゴン座標を採取 し, ポリゴン座標データを採取するとともに, 単 位メッシュ長:UL にドット網を重ね合わせ, 各構 造種別毎のドット占有率をカウントして建物混成 比のデータを採取していた，弚のため，対象地域 が広域となるとデータの採取に多大な時間と労力 を費やしていた．炎の結果，誰もが容易にインプ ットデータを採取することは困難であった . 乥こ
で，次節で述べるように，データ入カのシステム 化を行い，データ採取の効率化を行った .

\section{( 2 ） データ入カのシステム化}

本節では, 著者らが改良を行った，都市構造デ 一タ入力のシステム化について述べる . 前述した ように，従来のデータ採取法は，ポリゴン座標の 入力データ, ポリゴン属性データ, ドットカウン 卜より算定されるメッシュデータ (属性, 各種構 造混成比，建ペイ率) のデータファイルを作成し ていた .ドットのカウントは手作業で行い,さら に，光れ光れ独立にデータファイルを作成してい たため, エラーの修正にも時間を要することがし ばしばであった .乥こで, 図- 2 に示すように ,a) ポリゴンデータファイル作成システム，b) 任意の 単位メッシュ長:UL を与えたとき,c) pi xel 值を力 ウントすることにより，メッシュ内の建物占有率 を算定する一連の入カシステムを開発した . 一連 の操作については，4.の適用事例で述べるが， 手作業の部分は, ポリゴンの端点をマウスでクリ ックすることと，ポリゴンの建物属性をマウスで クリックするのみである .この結果 , 誰でも容易 に , シミュレーションのインプットデータである 都市構造データを採取することが可能となった .

\section{3. 都市計画・防火樹木配置効果の評価システム}

\section{（1）開発システムのフロー}

著者らは，住民・行政が地域のデータを自ら採 取し 地域の地震火災色険性を提示するとともに， 沿道建物の耐火化や，防災樹木の配置の効果を即 時評価可能なシステムの開発を目的としている . ぞのために，2．で述べたように，都市構造デ 一タの採取ならびに , シミュレーション・パラメ 一タの作成の効率化を図った .この段階で, 住民・ 行政は, 気象条件と出火点を入力すれば, 設定し

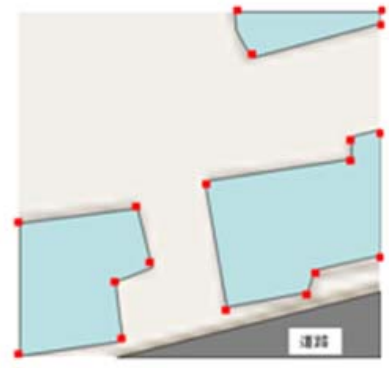

a)ポリゴンデータ入力

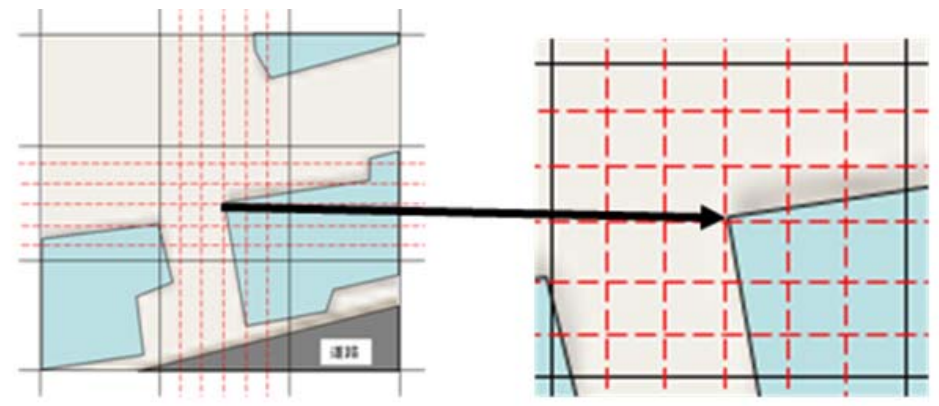

b)メッシュ分割 c) Pixel 值のカウント

図-2 シミュレーション・インプットデータ作成のシステム化 
た単位時間: UT 毎の延焼リスクを視覚的かつダイ ナミックに認識できる. 产の結果, 避難路の火災 リスクや，地域の延焼危険性が明確になるととも に，“何らかの対策が必要となる”といった意識 が高まるであろう .

本節では，具体的な対策と光れらの効果を即時 反映可能なシステムの開発を行った、図- 3 に開発 システムの全体フローを示す．

図-3の上側は，2．で概説した，都市構造デー

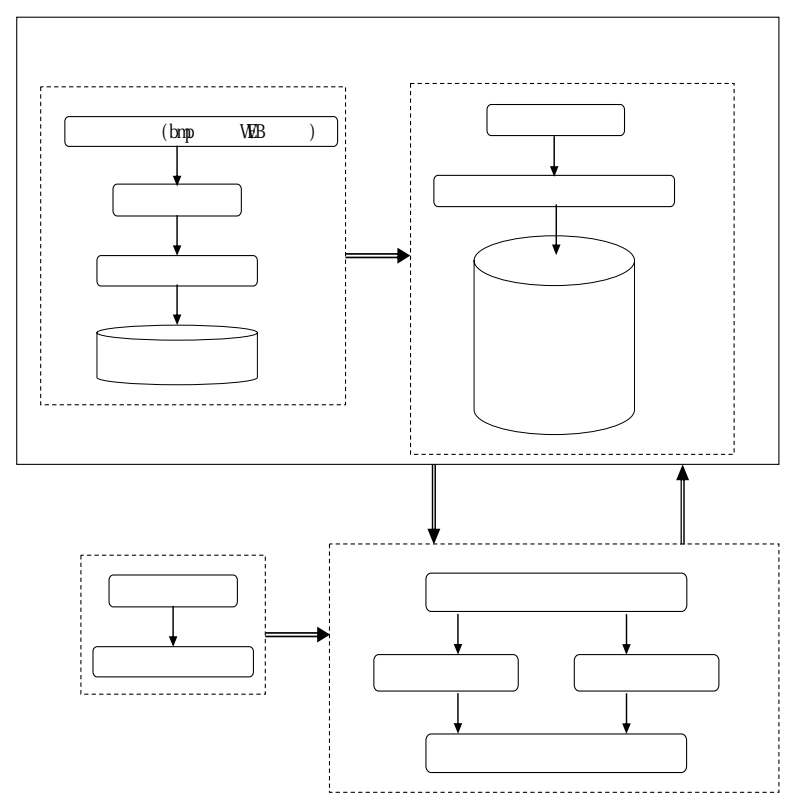

図-3 開発システムの全体フロー

表-1 緑地焼け止り率に関するデータ ${ }^{9)}$

\begin{tabular}{|c|c|c|c|}
\hline 大火の名称 & 発生年 & 風速 $(\mathrm{m} / \mathrm{sec})$ & $\begin{array}{l}\text { 緑地焼け } \\
\text { 止まり率 }(\%)\end{array}$ \\
\hline 関東大震火災 & 大正12 & $11.3 \sim 21.8$ & 33.3 \\
\hline 静岡大火 & 昭和 15 & $18.0 \sim 22.0$ & 25.4 \\
\hline 那珂湊火災 & 昭和 22 & 2.2 & 33.3 \\
\hline 福井大震火災 & 昭和 23 & 3.0 & 48.1 \\
\hline 熱海火災 & 昭和 25 & 2.2 & 38.5 \\
\hline 鳥取火災 & 昭和 27 & $7.9 \sim 10.8$ & 50.0 \\
\hline 岩内火災 & 昭和 29 & $4.2 \sim 21.7$ & 21.3 \\
\hline 新潟火災 & 昭和 30 & $5.0 \sim 20.0$ & 20.4 \\
\hline 能代火災 & 昭和31 & $11.5 \sim 14.5$ & 33.7 \\
\hline 酒田火災 & 昭和 51 & $10.0 \sim 26.4$ & 10.5 \\
\hline
\end{tabular}

表-2 樹木の耐火カデータ

\begin{tabular}{|c|c|c|c|c|}
\hline & 常緑広葉樹 & 落葉広葉樹 & 針葉樹 & 木材 \\
\hline $\begin{array}{c}\text { 発火限界 } \\
\text { 輻射 } \\
\left(\mathrm{kcal} / \mathrm{j}^{2} \mathrm{~h}\right)\end{array}$ & 13,400 & 13,900 & 12,000 & 4,000 \\
\hline 引火限界 & & & \\
有炎口火 & 5,400 & 5,800 & 2,500 \\
無炎口火 & 5,700 & & & \\
\hline
\end{tabular}

タの作成システムである . 左側は, web 住宅地図 を背景画像としてシステムに取り込み，マウスで ポリゴンデータの端点を入力し，建物種別も合わ せて入力する . 以上の処理で, ポリゴンデータフ アイルが作成される．右側の部分は，延焼計算に 必要なパラメータ作成部分である。任意の単位メ ッシュ長 : Uしを与えると, ポリゴンデータファイ ルを参照しながら , pi xel 值をカウントすること によってメッシュデータが自動的に作成される．

次に , 図-3の下側左部分は, 出火点の入力並び に，風向，風速の設定，右部分はシミュレーショ ンの実行部分である.当該地域の卓越風や, 最大 風速など，シナリオに応じた条件を設定する . 例 えば，風向，風速，出火点を変えることにより， 延焼リスクが大きく異なることが即時に提示され る.シミュレーション実行部分の下側は, 具体的 な対策 (建物の不燃化，防火樹木の配置効果) を 即時評価するためのインターフェイスの開発を行 つている.建物の不燃化を行う場合は, 単にポリ ゴンデータの属性の変更を行えばよい．建物の配 置換えや, オープンスペースの追加等の場合は, ポリゴンデータを修正あるいは削除すると，自動 的にメッシュ・パラメータも修正される. 弚れら のデータを用いて，シミュレーションを再実行す ることにより，対策効果を即時に見ることができ る 樹木の配置効果については，次節で概説する .

\section{（２）防火樹木配置支援システム}

住民参加と合意形成に基づき，都市計画的な防 災対策を進めるためには，住民・行政が自らデー タを採取し，地域の危険性を認識し，防災対策と 乥れらの効果を視覚的かつ定量的に分析可能なシ ステムが有効であると考えている．防火樹木の配 置による不燃化計画は，環境や景観，実行可能性 の点でも魅力ある計画であると考えている．乥こ で，防火樹木の配置計画支援のインターフェイス を開発し，計画の即時評価システムを提案する。

\section{a) 防火樹木の耐火効果}

緑地の防火効果については, 表 1 に示寸過去の地 震火災, 都市火災における緑地関連の焼け止まりデ 一タを論拠の一つとしている. 表1より, 多くの大火は 強風時に発生していること, そして, 緑地で焼け止ま り効果が, 10.5〜 50.0\%と大きな効果があることが分 かる. 焼け止まり率のばらつきについては, 当然火災 の形状や, 樹木の種類・状態によるものと考えられる. この樹木の耐火力に関する研究は, 「岩河」9 ${ }^{9010)}$ が, 
樹種, 配置, 熱量に関する実実験を行い整理してい る. 表 2 は, 樹木の耐火力に関するデータの一覧で ある。表 2 より，木材の発火限界輻射熱 $4,000 \mathrm{kcal} / \mathrm{m}^{2} \mathrm{~h}$ に対して, 常緑広葉樹の発火限界輻 射熱量は, $13,400 \mathrm{kcal} / \mathrm{m}^{2} \mathrm{~h}$, 針葉樹が 12,000 $\mathrm{kcal} / \mathrm{m}^{2} \mathrm{~h}$ と高い值となっている. 換言すれば, 木材に 比べて高い耐火力を持っていることが分かる. 表 2 の 下段は, 飛び火のような口火があった場合の引火限 界值である。

防火樹木の耐火力の判定は, 図-4に示すように, メッシュ型シミュレーションによる火炎面と樹木帯の位 置関係を基にして, 輻射受熱量の計算を行い, 表2の

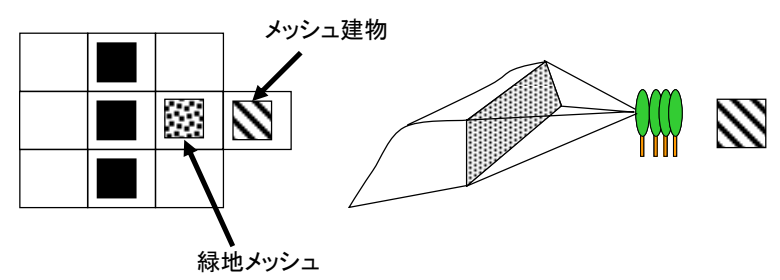

図-4 メッジュの延焼領域と輻射熱算定モデル

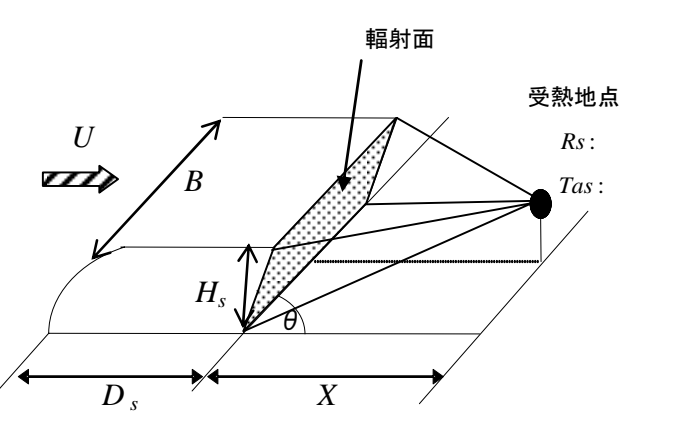

図-5 同時炎上領域と樹木受熱量の関係

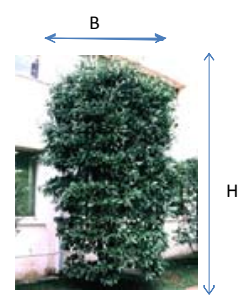

a)サンゴジュ

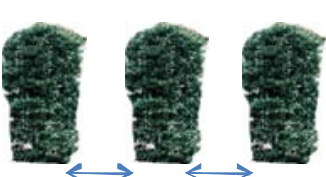

$\mathrm{B} / 2$

$\mathrm{B} / 2$

c)(2) 葉張 $1 / 2$

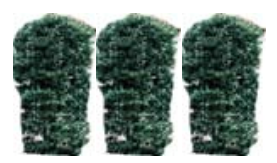

b)(1)隙間無し

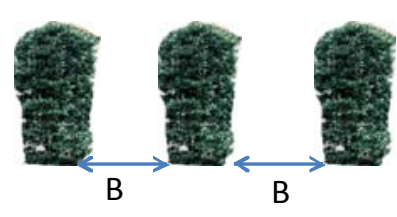

d)(3)葉張
図-6 サンゴジュの配置パターン(高さ H,葉張:B)
樹木の耐火力データを用いて判定するといらモデル である. 次項では, 樹木の配置パターンと防火効果 の算定方法について述べる.

a) 防火樹木の配置パターンと遮蔽効果

著者らが開発してきた防火樹木配置効果システム 4), 5) は, 岩河の研究9, 10)をべースに, 構成している. 寸なわち, 図-4では, ロで表示されたメッシュが延焼 中のメッシュであり, それが同時延焼領域となり,この 領域加火炎領域 (火炎高さ・幅・傾き)を定め, そこ からの受熱量を算定している. 具体的には, 図- 5に 示すように, 風速U $(\mathrm{m} / \mathrm{sec})$ によって, 火炎領域 $\left(\mathrm{H}_{\mathrm{s}} \times\right.$ $\left.\mathrm{B} \times \mathrm{D}_{\mathrm{s}}\right)$ が $\theta$ 傾いた輻射面から X(m) 離れた位置の受 熱量を, 輻射熱 $R_{s}$ と対流熱 $T_{\mathrm{as}}$ の和として算定している. この輻射面と受熱地点の間に防火樹木を配置寸れ ば, 熱量の遮蔽効果が期待できる. 本研究では, 常 緑広葉樹であるサンゴジュ(成木: 高さ 5 〜 7 ) を配 置するとして, 図- 6に示す配置パターンと樹木高さを 入力データとして与えることとする.これらの配置パタ ーンによる熱量の遮蔽率は, 表3の岩河らの文献9, 10) に基づいている.

\section{表-3 配置パターンと遮蔽率}

\begin{tabular}{|l|c|}
\hline 隙 間 & 遮蔽率 (\%) \\
\hline 無し & 73.1 \\
\hline 葉張 $1 / 2$ & 48.7 \\
\hline 葉張 1 & 24.3 \\
\hline
\end{tabular}

著者らの従来のシステム4) は, 火災の延焼シミュレ ーション結果を基に, 樹木の高さ, 遮蔽率, 樹木位置 を外生的に与え, 別途シミュレーションを実行して, 配 置効果による延焼阻止効果を判定していた. しかし, プログラムの書き換えや, 別のインターフェイスを利用 してパラメータを入力する必要があり, 必ずしもユー ザフレンドリーなインターフェイスとはなっていなかっ た. そこで, 4. の適用事例で示すように, シミュレーシ ヨン表示画面上で配置パターン並びに, 樹木の高さ を入力し, 即時実行並びに効果を判定できるシステ ムへと改良を行った. 以上より, 配置パタンーが限定 的ではあるが，住民・行政が，地域の防火力を高める 手段としての防火樹木の配置とその効果を即時評価 可能なシステム構成を行った. システム開発環境は, Wndows XP上で, M crosoft Vi sual Basi c 6.0を 用いて開発している.

\section{4. 適用事例}


3.では, 住民・行政が地域の地震火災危険性 を評価し，都市計画的な対策や，防火樹木の整備

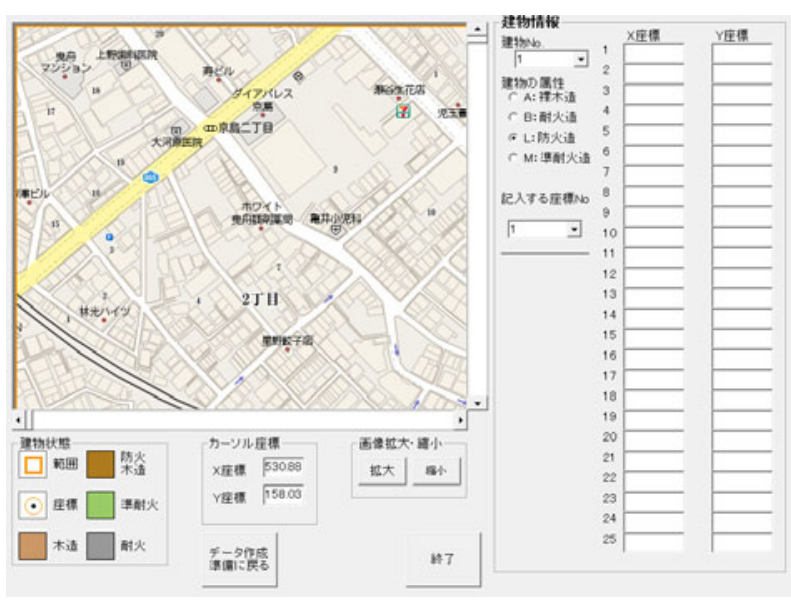

図-7 ポリゴンデータ入カシステム
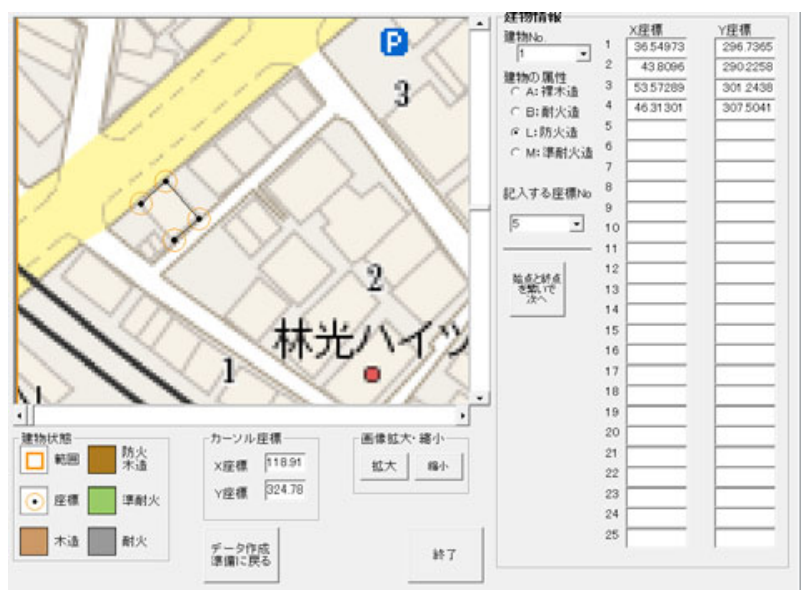

図-9 ポリゴン端点座標入力 (建物 ID.No.1)

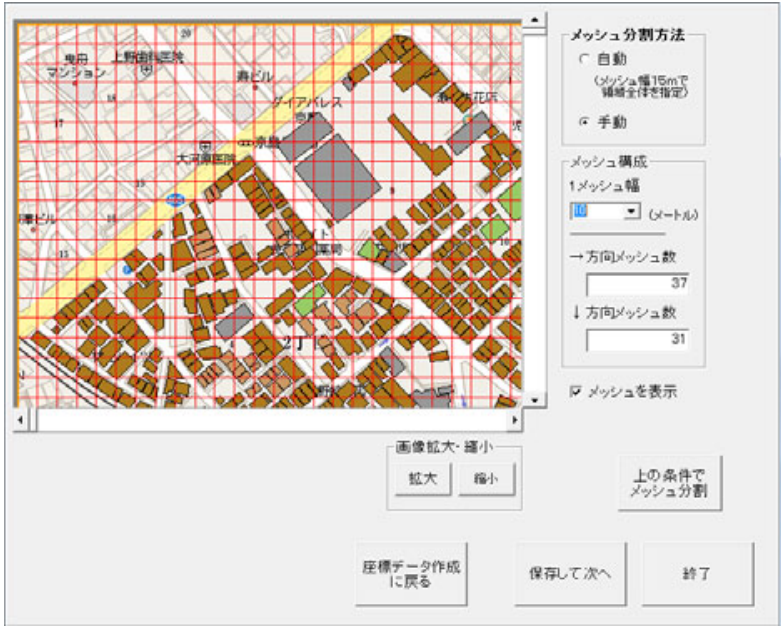

図-11 メッシュ分割 $(U L=10 m)$ とインプットデータ生成
対策の効果を確認できるシステム開発を行った . 本章では, 適用事例を通して, システムの操作性

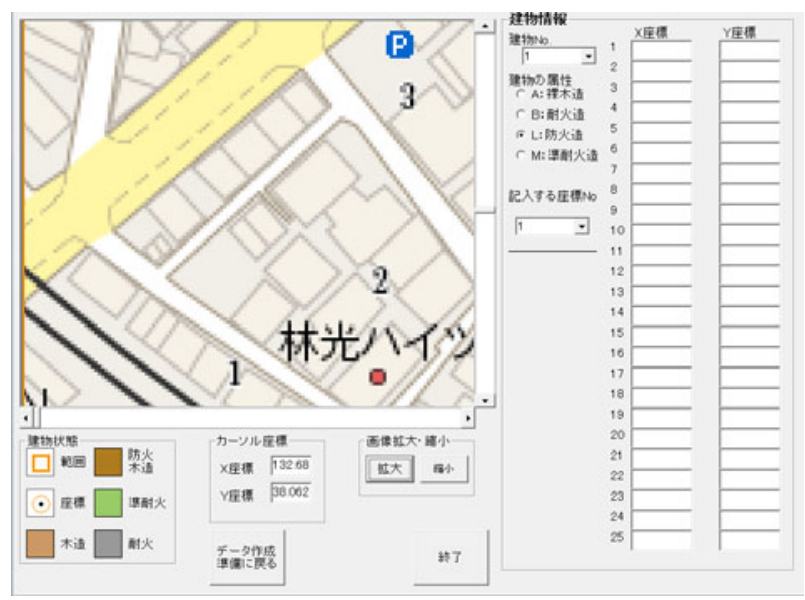

図-8 ポリゴンデータの拡大機能

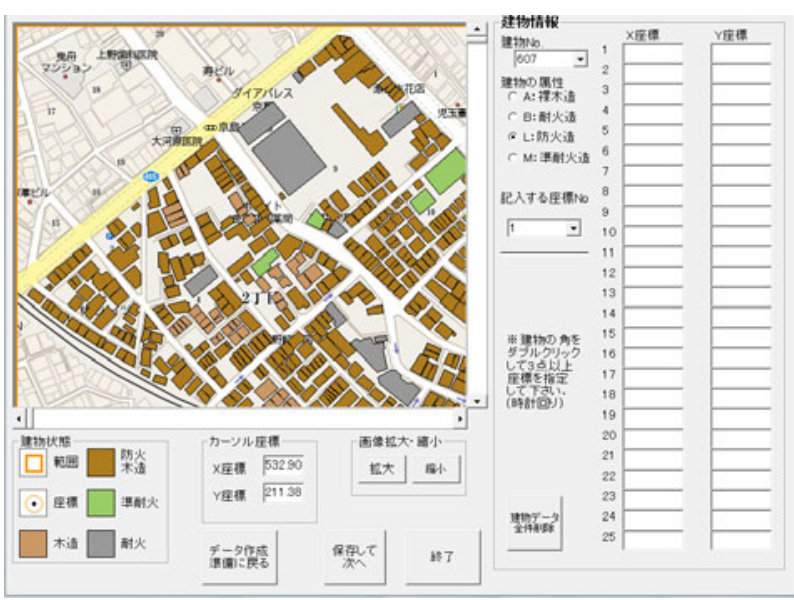

図-10 ポリゴンデータの登録完了

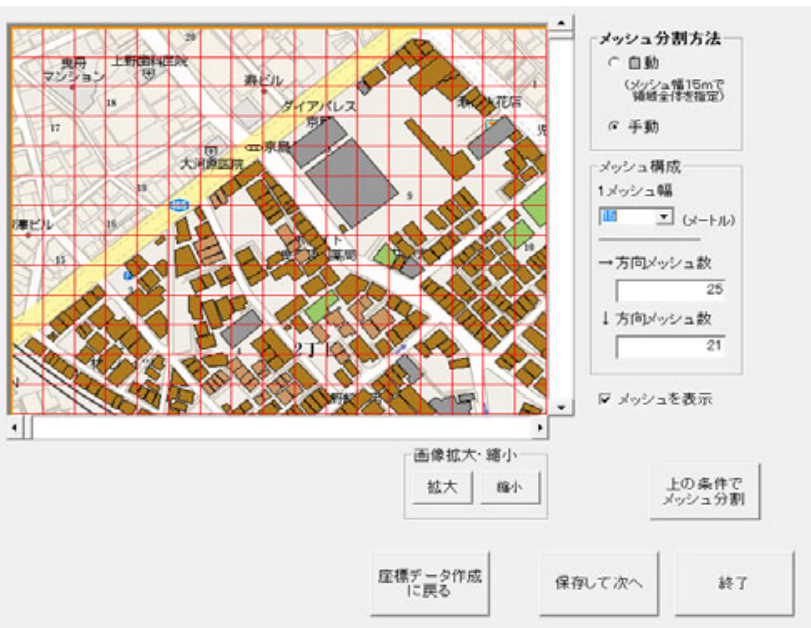

図-12 メッシュ分割 $(U L=15 m)$ とインプットデータ生成 


\section{並びに実効性の検証を行う .}

\section{（1）都市構造データ作成事例}

图-7に，ポリゴンデータ入カシステムを示す． 背景の住宅地図は東京都墨田区の木造密集市街地 で, web 上の住宅地図のbi t map 画像を用いている . 図- 7 の右側インターフェイスは, ポリゴンIDの 登録と位置座標登録のための画面である . 具体的 には，当該ポリゴンの端点座標をマウスでクリッ クしながら一軒ずつデータ化する .このとき，図8 に示すように，画面の拡大・縮小ボタンをクリ ックしながら作業を効率的かつ正確に行えるよう に工夫している．ポリゴンの属性は，画面の下の 建物状態 (木造, 防火木造, 準耐火構造, 耐火構 造) をマウスで指定する. 図-10 は, 対象エリア の全てのポリゴンデータを入力した画面である . 図より, 対象地域は, 木造，防火木造の建物が主 であり，道路沿道建物も殆ど耐火化されていない ことがわかる . 図下の，“保存して次へ”をクリ ックするとポリゴンデータファイルが生成される . 一般的に，住宅地図からのみでは，ポリゴンの

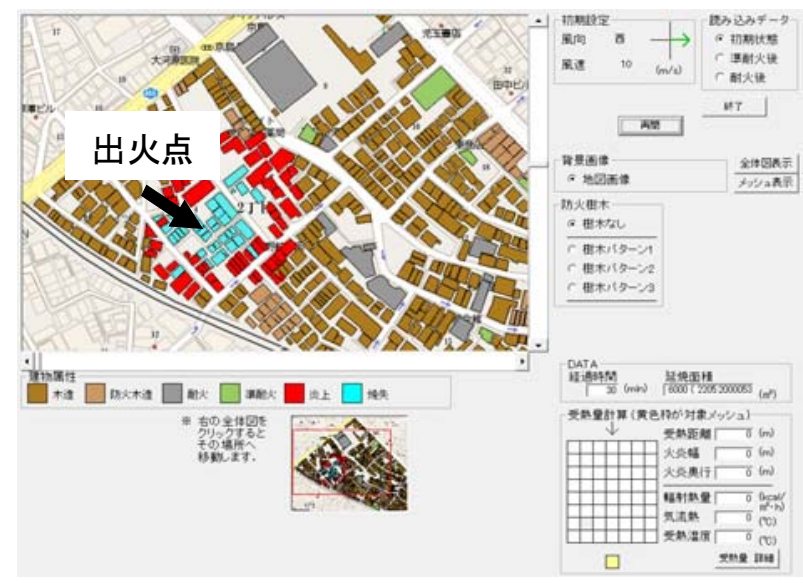

出火点 1 、西風、 $10 \mathrm{~m} / \mathrm{sec}$ 、焼失面積 $0.6 \mathrm{ha}$ 図-13 シミュレーション事例 (30 分後)

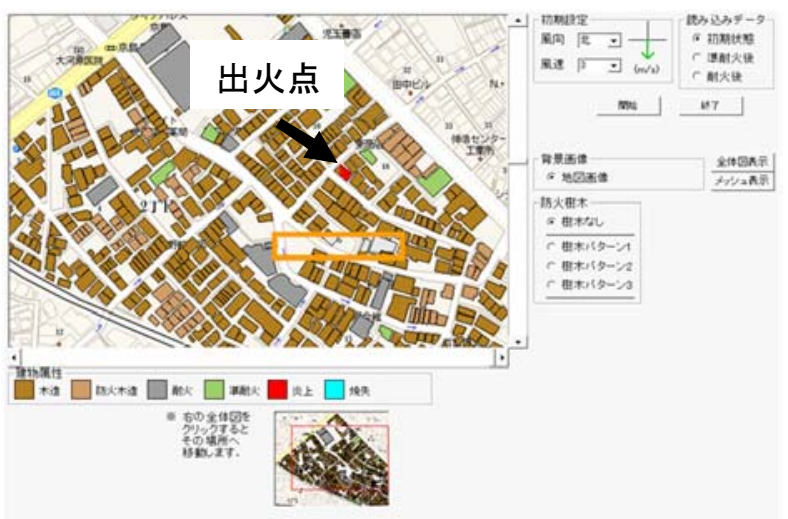

出火点 1 、北風、 $3 \mathrm{~m} / \mathrm{sec}$

図-15 木造建物のオープンスペース化
属性判別のための正確な情報は分らない．しかし， 住民・行政が，自分の住んでいる地域のデータを 採取するのであれば，属性の定義を明記すれば問 題は少ないと考えられるが，インターフェースに 工夫が必要であろう .

図-11 は, 単位メッシュ長 : UL=10(m) でメッシ ユ分割 (横方向 37 メッシュ , 縦方向 31 メッシュ の正方分割) している.単位メッシュ長 : UL 入力 すれば，自動でメッシュが掛けられ，建物属性の pi xel 数を自動カウントして, 図 2で示したメッ シュモデルの家屋長，隣棟間隔等のデータが自動 生成される.図-12 は,単位メッシュ長 : UL=15( m) と入力した場合（横方向 25 メッシュ，縦方向 21 メッシュ）を示す. 対象地域は，狭小な建物が多 く存在するため，以後，UL=1O(m) に設定する . 図 - 11,12が示すように ,図-10のポリゴンデータ座 標と属性が入力されれば, 実行単位のメッシュ 長: UL を入力すれば, シミュレーションに必要な インプットデータが自動生成される .

以上より，従来，対象地域が広がるにつれて指 数状に掛かっていた入力データの手間が大幅に

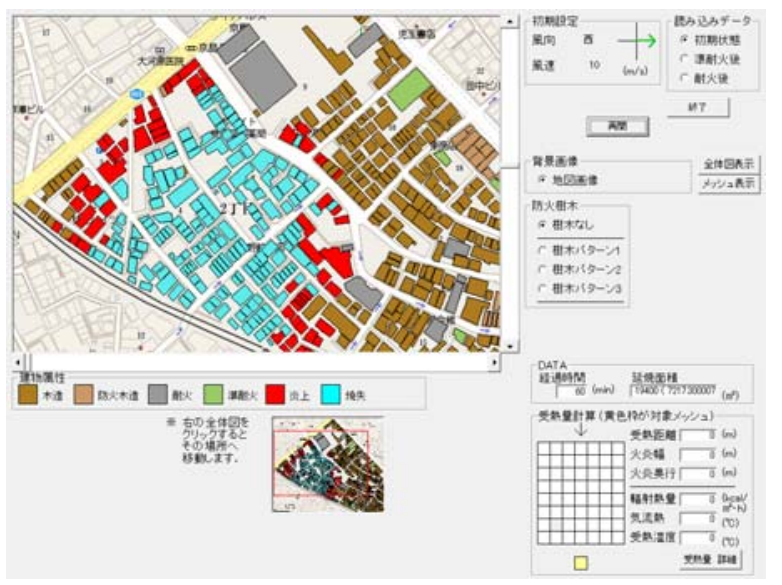

出火点 1 、西風、 $10 \mathrm{~m} / \mathrm{sec}$ 、焼失面積 1.94ha 図-14 シミュレーション事例 (60 分後)

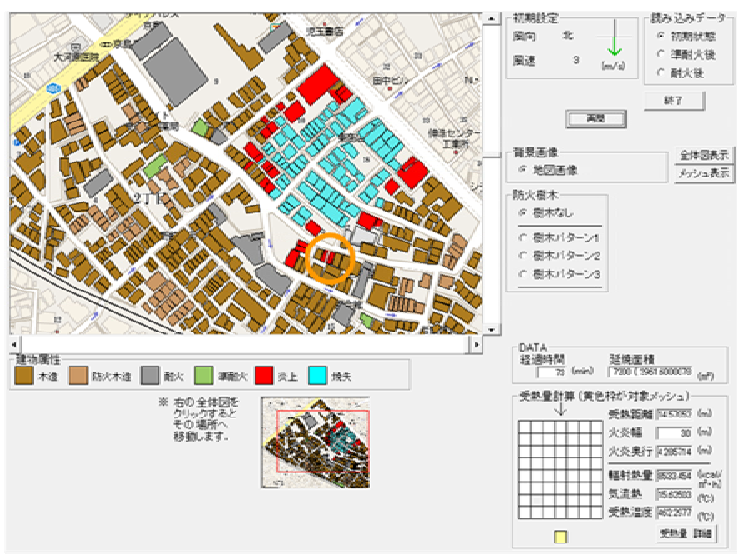

出火点 1 、北風、 $3 \mathrm{~m} / \mathrm{sec}$ 図-16 風下二次近傍への延焼 
短縮化されるとともに，ヒューマンエラーに伴う データの信頼性の低下も解消されている .

\section{（ 2 ）都市計画·樹木配置計画と評価}

図-13 は，出火点を画面中央に一個所設定し， 風向を西風，風速を，10m/secで設定した，30分 後の延焼動態図である．延焼面積は，0.6ha であ る.ちなみに, 風速を $3 \mathrm{~m} / \mathrm{sec}$ で設定すると, 同じ 時間での焼失面積は $0.12 \mathrm{ha}$ と, 風速が $10 \mathrm{~m} / \mathrm{sec}$ の $1 / 5$ の值となった .このことより, 強風時の地 震火災の危険性は, 非常に高く, 近年発生した地 震時の気象条件を考慮すると, 火災に対しては不 幸中の幸いだったといえよう．

図-14の出火後 60 分の延焼動態図を見ると,地 図上の左上から右下へ走る幹線道路を越えて火災 が東側に延焼拡大している状況が分かる.このま までは, 時間の進行とともに, 東側の木造密集市 街地も火災の延焼危険性があることが分かる．紙 面の制約上割愛するが, 出火後 152 分で, 画面下 側の全体マップの領域すべてを焼失した 。

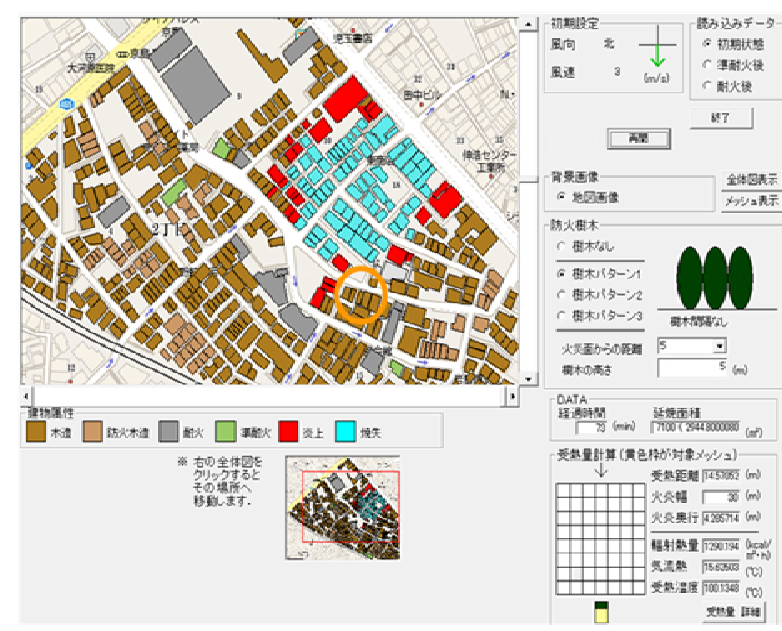

図-17 樹木配置効果(隙間無し)

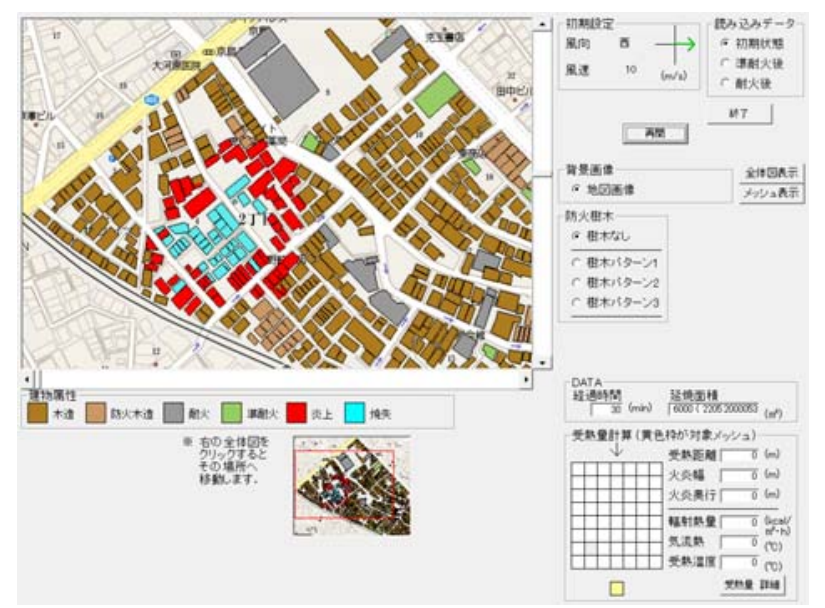

図-19 樹木配置効果 (葉張 1)
図- 15 は, 地図上の右下部分のオレンジで囲ま れた部分の建物 2軒をオープンスペースに置き換 えた図である .すなわち , オレンジのオープンス ペース群で延焼の遮断効果の判定を行う.図-9の ポリゴンデータ作成部分に戻り, 該当する建物を 消去し，別の名前でデータファイルを作成する . 沿道建物の属性の変更についても，図-9のポリゴ ンデータ作成部分で修正をかければよい．新しく 作成したポリゴンデータは，図-11 のメッシュ分 割を行い，インプットデータを生成する．以後， これらのデータを用いてシミュレーションを実行 すればよい .

図-16は,図-15のデータを用いて, 出火点を図 - 15 に示す地図上中央右側に設置し, 北風，風速 $3 \mathrm{~m} / \mathrm{sec}$ の同じ条件でシミュレーションを実行し た結果である . 図-16より，風下二次近傍への延 焼が確認された . 弚こで，防火樹木の配置による 延焼遮断対策を行う.

図-17 は, 図-16で風下二次近傍への延焼が確認 された，○の中の建物の前面に樹木を配置して延

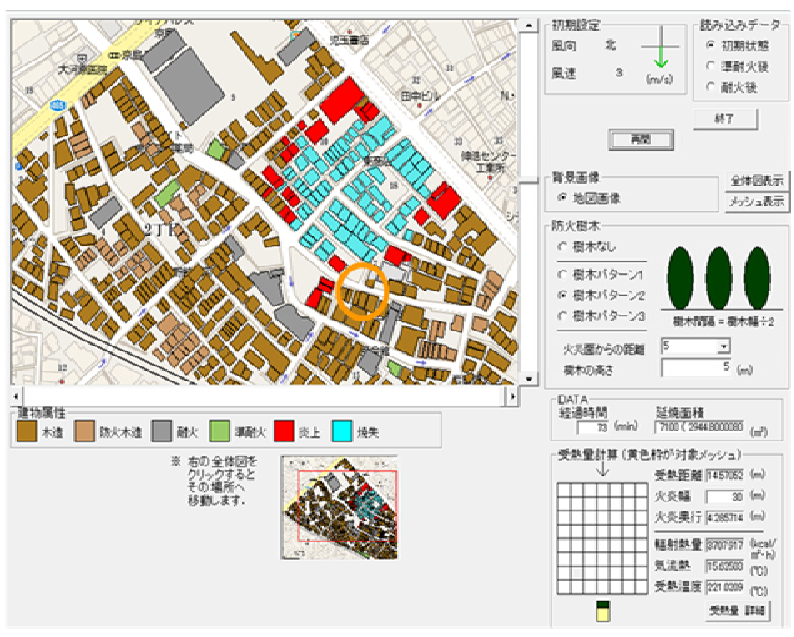

図-18 樹木配置効果 (葉張 1/2)

表-4 配置パターンと背面家屋受熱量

\begin{tabular}{|l|c|c|c|}
\hline パターン & 隙間無し & 葉張 1/2 & 葉張1 \\
\hline 受熱温度 $\left({ }^{\circ} \mathrm{C}\right)$ & 101.1348 & 221.0209 & 341.907 \\
\hline
\end{tabular}

焼遮断効果を確認することにする . 図-13以降の シミュレーション実行画面の右側に, 樹木の配置 パターンの選択画面がある.樹木の配置パターン は, 図一6に示したように,パターン1が，隣接す る樹木の葉長間隔無し パターン 2 が 葉張の $1 / 2$ 間隔, パターン 3 が, 葉張間隔である. 図-17〜 19 に示すように, 配置パターンをクリックする と，簡単な配置パターン図が左側に表示される． 
図-17〜19 に示すように, 配置パターンをクリッ クすると, 簡単な配置パターン図が左側に表示さ れる. 兴の下側の入力画面に，樹木の高さ $\mathrm{H}(\mathrm{m})$ と，配置する樹木までの垂直距離 $\mathrm{z}(\mathrm{m})$ を入力する


したパターン, 図- 18 は, 葉張の $1 / 2$ の間隔で配 置したパターン, 図-19 は, 葉張の間隔で配置し たパターンである . 各々の背面家屋が受けた最大 の受熱量を表 4 に示す .この表より，いずれのパ ターンも木材の発火温度 $400^{\circ} \mathrm{C}$ より小さく, 風 下への延焼を防火樹木が阻害していることが分か る。

以上を整理すると，都市計画的な対策 (可燃建 物からオープンスペースの新設) を行っても，十 分な火災リスクの低減に繋がっていないため, 防 火樹木の配置 (3 パターン) の防火効果を検討し た . 兴の結果, 全てのパターンで防火効果か認め られた．ただし，本事例は一例であり，風速や出 火点の設定によっては，十分な防火力を持たない ことも想定されよう. . 今後, 住民参加の下, 種々 のシナリオで, 自らの代替案を評価・検討するツ ールとして,地震火災リスクを“自分の問題・地 域の問題”として認識を深める効果が期待できよ j.

\section{5.おわりに}

大震時の地震火災の危険性は, 発生時の気象条 件や出火の状況によって大きく異なる．一般認識 として, 近年, 甚大な被害を出した地震火災は発 生していない,しかし, このことは, 地震の発生 時間帯や気象条件が幸いしていたにすぎない，特 に, 木造密集市街地では, 従来の長期的な面的整 備のみならず, 即時的な対策として, ポケットパ 一クのようなオープンスペースや防火樹木の配置 計画を進めていくことが肝要であろう. そ光のため にも，住民自らが地域の地震火災の危険性を認識 し，対策の効果を検討するシステムが有効となろ う. 本研究では, 著者らが開発を行ってきた大震 時の火災延焼シミュレーション・システムの入力 系・出力系の改良ならびに, 具体的な防火対策の ためのインターフェイスを開発した .

具体的には，住民・行政が自分たちの地域のデ 一夕採取から, 分析, 対策と光れらの評価といっ た一連の適用を可能とするシステム開発を行った . 適用事例を通して, web で提供される住宅地图を 背景画像とし，ポリゴンデータと属性の入力によ る, シミュレーション用の都市構造パラメータ自 動生成システム開発を行った，光して，建物の才
ープンスペース化の効果や，防火樹木配置対策の 組み合わせにより，延焼阻止効果を確認すること ができた . 紙面の制約上割愛したが , 沿道建物の 耐火化によるブロック効果についても同樣に評価 できる .

以上は,火災の延焼リスクの提示, 対策の効果・ 評価に関する視点であるが，今後，避難路・避難 場所の火災熱リスクの提示, 対策・評価システム を組み込みたいと考えている．さらに，著者らが 開発している，ペトリネットによる避難計画支援 システム ${ }^{11)}$ と連動したシステム開発を行いたい と考えている . 後者の, 避難計画支援システムに ついても，住民・行政が自ら操作可能なレベルま でのシステム開発，インターフェイスの改良を行 う必要があると考えている .

今後のシステムの課題としては, 開発したシス テムを，実際に住民・行政に使っていただき，ワ ークショップ, アンケート・ヒアリングを通じて 課題・問題点を抽出するとともに, 実運用レベル での汎用性を高めていきたいと考えている .

\section{参考文献}

(1)木俣昇: 大震時避難計画のためのメッシュ型火災延焼シミュレ ーション・システムに関する検証, JORSJ,30-1,pp.59 86,1987.

(2)木俣昇, 二神透: 福光大火のシュミレーションと復興計画の評価, 金大教育開放センター紀要 8, pp.73 84,1987.

(3)二神透, 木俣昇, 和田修司: 路上車両火災を考慮した地震時 火災シミュレーションに関する基礎的研究, 土木計画学研究・論文 集, No.16,pp.349-356, 1999.

(4)二神 透, 木俣 昇: 火災延焼シミュレータを用いた防火樹木整 備支援システムの開発, 土木計画学研究・論文集, No.23, pp.325-334,2006.

(5) 二神透, 木俣昇:防災緑地網整備計画のための火災延焼シミ ユレーション・システムの拡張化に関する基礎的研究, 土木計画学 研究·論文集, No.12,pp.151-159, 1995.

(6)日本火災学会編 (第2版) : 火災便覧, 共立出版, 1984.

(7) 日本火災学会編 (第3版) : 火災便覧, 共立出版, 1997.

(8)系井川栄一: 震災時の火災延焼シミュレーションー現状報告・ 将来の行方一, 2004予防時報217, pp.30-35,2004.

(9)岩河信文: 樹木の防災効果について, 公園緑地, 38-2, pp32-40,1977.

(10) 岩河信文: 都市における樹木の防火機能に関寸る研究, 建 築研究報告, No.105,1984

(11)二神 透, 木俣 昇: 中山間地域の救急・避難計画のため のシナリオシミュレーションの開発, 土木計画学研究・論文集, No.15, pp.89-96,2005. 